\title{
Ocular and Orbital Injury in All-Terrain Vehicles: A Literature Review
}

\author{
Elliot S. Crane ${ }^{1}$, Anton M. Kolomeyer ${ }^{2}$ and Andrew W. Eller ${ }^{2, *}$ \\ 1 Institute of Ophthalmology and Visual Science, Rutgers-New Jersey Medical School, Newark, NJ 07101, \\ USA; cranees@njms.rutgers.edu \\ 2 Department of Ophthalmology, University of Pittsburgh School of Medicine, Pittsburgh, PA 15213, USA; \\ tosha82@gmail.com \\ * Correspondence: elleraw@upmc.edu; Tel.: +1-412-647-2200, Fax: +1-412-647-5119
}

Academic Editor: Raphael Grzebieta

Received: 3 November 2015; Accepted: 17 October 2016; Published: 26 October 2016

\begin{abstract}
Purpose: To review primary literature on ocular and orbital injury secondary to all-terrain vehicles (ATVs). Methods: A Medline search of English language literature. Results: Very few studies detail ocular and orbital manifestations of ATV crashes. The most common ocular injuries included orbital fractures and eyelid lacerations. Less common but more severe injuries included traumatic optic neuropathy, retinal detachment, optic nerve laceration, and ruptured globe. Associated facial and skull bone fractures, traumatic brain injury, and subdural/subarachnoid hemorrhage were not uncommon. Depending on the mechanism and force of injury, complete loss of vision has been documented. Conclusion: Ocular and orbital trauma can be found in many cases of ATV-related injury. Various interventions may decrease the frequency of such injuries, including use of head and eye protection.
\end{abstract}

Keywords: all-terrain vehicle; ocular injury; orbital injury

\section{Introduction}

All-terrain vehicles (ATVs) are popular recreational vehicles originally introduced in 1971. Between 1982 and 2014, the Consumer Product Safety Commission (CPSC) received 13,617 reports of ATV-related fatalities [1]. Based on crash frequency data, and in coordination with the CPSC, the more-dangerous three-wheeled ATVs were discontinued in 1988 [2,3]. The Consumer Product Safety Improvement Act, which became effective in 2009, reinforced the ban on three-wheeled ATVs and established the process through which the CPSC adopts and amends mandatory standards for ATV manufacture [4].

Multiple studies have outlined factors that increase the inherent risk associated with ATV use, including: no training or licensing requirement, ability to achieve high speeds (up to $65 \mathrm{mph}$ ), heavy weight (up to $600 \mathrm{lbs}$ ), lack of requirement for use of personal protection (e.g., helmets and goggles), use in areas with poor terrain, riding with passengers, and riding on roadways [5-13]. ATV-related injuries occur most commonly in males, in the age range late teens-early 20 s, on weekends, in the evening, and during summer months. The CPSC estimates that in 2011 (the most recent year with finalized data), ATVs were responsible for more than 100,000 injuries treated in emergency departments and nearly 700 deaths in the United States [1]. Texas, California, Pennsylvania, West Virginia, and Kentucky had the highest numbers of ATV-related fatalities from 1982-2011, each with over 500 deaths for the reporting period [1]. From 2001-2008, an average of 144 children and 568 adults died each year from ATVs in the United States. The American Academy of Pediatrics policy on ATVs recommends that ATV riders should be required to wear motorcycle-style helmets, to be at least 16 years old, to not carry passengers, and to not ride after sunset or before sunrise [14]. 
Of the estimated 93,700 emergency department-treated ATV injuries in 2014, 28\% involved the head and neck [1]. This is similar to a 2001 report by Cvijanovich et al. that describes head or spinal cord injury in $25 \%$ of pediatric ATV injuries in Utah [15]. Although head and face trauma constitutes one of the most common types of injury related to ATV crashes, few studies have been published on ophthalmologic sequelae $[5,6]$. We review the primary literature on ocular and orbital injuries secondary to ATV crashes, and provide recommendations based on our review.

\section{Methods}

Medline was searched for articles related to ocular or facial ATV injuries in the English language (Appendix A), resulting in 61 articles. Twenty-five were deemed unrelated based on title and abstract review. The full manuscripts of the remaining 36 were screened for relevance. Articles that involved a retrospective or prospective review of ocular or orbital injuries secondary to ATV crashes were included. Thirteen articles met these inclusion criteria. References from these 13 articles were also screened for inclusion, resulting in one additional included article. Overall, 14 articles were included in the literature review.

\section{Results}

The 14 included articles were divided into three categories. Three articles (101 patients) were dedicated primarily to detailing ATV-related ocular injuries, including orbital fractures (Table 1). Eight articles (666 patients) described ATV-related orbital fractures (Table 2). The three remaining articles (311 patients) described pediatric ATV-related injuries, but only briefly mentioned ocular involvement (Table 3).

\subsection{Articles Dedicated to ATV-Related Ocular Injuries}

Edmonson et al. documented ophthalmic injuries secondary to ATV crashes in 20 children (mean age, 11.1 years; $70 \%$ male) [5]. Many sustained orbital fractures (see Table 1), and 25\% had eyelid lacerations. Two patients (10\%) had traumatic optic neuropathy (TON) with final visual acuities (VA) of count fingers and no light perception (NLP). Edmonson et al. also detailed a sample case presentation of a 12-year-old boy. The front wheel of his ATV came off while driving without a helmet, causing the ATV to flip over and the handle bar to penetrate his left orbit and brain. This resulted in TON, an $8.5 \mathrm{~cm}$ facial laceration, multiple facial and orbital fractures, and a cerebrospinal fluid leak requiring an emergent craniotomy. His VA remained at NLP, though he had otherwise full neurologic recovery.

Close et al. documented a case of a 13-month-old boy who fell from an ATV and developed periorbital cellulitis three days later. No foreign body was found upon orbital surgical exploration or fundoscopic exam. The cellulitis persisted despite antibiotic therapy, and an ultrasound eventually revealed an intraorbital wooden foreign body, which was removed surgically. Six month ophthalmic follow-up "revealed no evidence of visual loss, nerve injury, or impairment of extraocular muscle function" [16]. No information was available on helmet use.

Mayercik et al. documented ophthalmic injuries secondary to ATV crashes in 80 patients (mean age, 23.5 years; $86 \%$ male) [6]. Ocular injuries were present in $16.1 \%$ of cases of ATV-related hospital admissions in this study. The most common ocular/orbital injuries included orbital fracture $(80 \%)$, periorbital ecchymoses $(40 \%)$, lid laceration $(25 \%)$, subconjunctival hemorrhage $(15 \%)$, and diplopia (10\%). More serious sequelae, such as TON, severed optic nerve, and ruptured globe were seen in $3.8 \%, 2.5 \%$, and $1.3 \%$ of patients, respectively. The most common, concomitant, non-ocular injuries included loss of consciousness (49\%), facial fractures (30\%), and subdural (14\%) and subarachnoid (13\%) hemorrhages; $2.5 \%$ of patients died. Only $24 \%$ of patients wore head protection, and none wore eye protection at the time of injury. One patient's regular corrective lenses shattered, which the authors believed to have compounded the ocular injury. In this report, the associated alcohol usage while operating an ATV was 38\% in adults and 5\% in children, while recreational drug use was documented in $3 \%$ of adults and none in children. 
Table 1. ATV-related ocular injuries. RR: Retrospective review. TON: traumatic optic neuropathy. TBI: traumatic brain injury. NI: no information.

\begin{tabular}{|c|c|c|c|c|c|c|c|}
\hline Article & Study Type & $\begin{array}{l}\text { Total Number of } \\
\text { Ocular ATV Injuries }\end{array}$ & 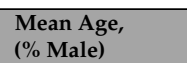 & $\begin{array}{l}\text { \% Alcohol Use (Drugs); } \\
\text { \% Helmet Use (Eye Protection) }\end{array}$ & Incidence of Ocular Injuries, n (\%) & Other Bodily Injuries & Mechanism of Injury \\
\hline 2004 Edmonson [5] & $\begin{array}{l}\text { RR at a level I trauma } \\
\text { center in Tennessee } \\
\text { from 1997-2002 }\end{array}$ & 20 , pediatric only & 11.1 years, $(70 \%)$ & $\mathrm{NI}(\mathrm{NI}) ; 0 \%(0 \%)$ & $\begin{array}{l}\text { Floor fracture } 4(20 \%) \text {, medial wall } \\
\text { fracture } 6(30 \%) \text {, eyelid laceration } \\
5(25 \%) \text {, lateral wall fracture } 2(10 \%) \text {, } \\
\text { trimalar fracture } 3(15 \%) \text {, roof fracture } \\
2(10 \%) \text {, TON } 2(10 \%) \text {, eyebrow } \\
\text { laceration } 1(5 \%)\end{array}$ & $\begin{array}{l}\text { Other facial fractures ( } 50 \%), \\
\text { TBI ( }(35 \%) \text {, Skull fracture }(30 \%), \\
\text { Orthopedic injury }(20 \%) \text {, one each } \\
\text { had: cervical spinal cord fracture, } \\
\text { hemiparesis secondary to TBI, other } \\
\text { facial laceration, spleen injury }\end{array}$ & $\begin{array}{l}11 \text { rollovers } \\
6 \text { collisions } \\
3 \text { unknown } \\
16 \text { drivers } \\
4 \text { passengers }\end{array}$ \\
\hline 2009 Close [16] & Case report from Ohio & 1 & $\begin{array}{l}13 \text { months } \\
\text { old, (100\%) }\end{array}$ & $\mathrm{NI}$ (NI); NI (NI) & $\begin{array}{l}\text { Periorbital cellulitis from intraorbital } \\
\text { wooden foreign body }\end{array}$ & 然 & Fall \\
\hline 2012 Mayercik [6] & $\begin{array}{l}\text { RR of trauma registry } \\
\text { in Pennsylvania from } \\
1998-2009\end{array}$ & 80 & 23.5 years, $(86 \%)$ & $20 \%(1 \%) ; 24 \%(0 \%)$ & $\begin{array}{l}\text { Orbital fracture } 64(80 \%) \text {, periorbital } \\
\text { ecchymoses } 32(40 \%), \text { lid laceration } \\
20(25 \%) \text {, subconjunctival hemorrhage } \\
12(15 \%) \text {, diplopia } 8(10 \%) \text {, cranial } \\
\text { nerve palsy } 7(9 \%) \text {, chemosis } 5(6 \%) \text {, } \\
\text { corneal abrasions } 5(6 \%) \text {, } \\
\text { enophthalmos } 5(6 \%), \text { TON } 3(3.8 \%) \text {, } \\
\text { severed optic nerve } 2(2.5 \%) \text {, restrictive } \\
\text { strabismus } 2(2.5 \%) \text {, traumatic cataract } \\
1(1.3 \%) \text {, ruptured globe } 1(1.3 \%)\end{array}$ & $\begin{array}{l}\text { Loss of consciousness }(49 \%) \text {, multiple } \\
\text { facial fractures }(30 \%) \text {, subarachnoid } \\
\text { hemorrhage }(12.5 \%) \text {, subdural } \\
\text { hemorrhage }(14 \%) \text {, rib fractures } \\
(11 \%) \text {, death }(2.5 \%)\end{array}$ & $\begin{array}{l}38 \% \text { rollover } \\
14 \% \text { fall } \\
11 \% \text { ATV vs. tree collisions } \\
1 \text { ATV drove off a cliff } \\
1 \text { ATV drove into a lake } \\
1 \text { eye struck with a stick } \\
\text { while driving in the woods } \\
3 \text { passengers }\end{array}$ \\
\hline
\end{tabular}


Mayercik et al. also detailed three case presentations [6]. The first regarded an intoxicated 24-year-old man who was struck in the eye with a rock while wearing a helmet but no eye protection. He sustained a canalicular laceration requiring surgical repair and an orbital floor fracture requiring surgical reconstruction and subsequent revision secondary to persistent diplopia and enophthalmos. The second case described an 11-year-old girl who was struck by a stick while riding her ATV through the woods with no helmet or eye protection. She sustained a corneal laceration and traumatic cataract requiring surgical repair, cataract removal, and implantation of an intraocular lens. The third case was of a 9-year-old boy whose ATV flipped over, and-similar to the case by Edmonson et al. - the handlebar impaled his left orbit and brain. He sustained bilateral optic nerve avulsions, orbital fractures, chemosis, and a lid laceration requiring multiple reconstructive surgeries. Systemically, he sustained multiple facial fractures, skull base fractures, penetrating brain injury, traumatic pancreatitis, and numerous superficial burns. His VA remained at NLP.

\subsection{Articles Describing ATV-Related Orbital Fractures}

Demas et al. described 35 pediatric ATV-related injuries from the Children's Hospital of Pittsburgh, a regional pediatric tertiary care trauma center [17]. Two $(6 \%)$ had isolated orbital-zygomatic fractures, and $82 \%$ of the injuries occurred in the summer months of April-September.

Marciani et al. published on 72 ATV-related injuries from the University of Kentucky Medical Center [7]. Seven (9.7\%) had orbital floor fractures, and two (2.8\%) required unilateral enucleations.

Touma et al. described 153 ATV-related injuries from West Virginia University Hospital's institutional trauma registry [8]. Twelve $(8 \%)$ had orbital floor fractures, one $(0.7 \%)$ had an orbital rim fracture, and four $(2.6 \%)$ had "ophthalmic" injuries. They noted that most of the injuries occurred in the summer months of May-July, and that "Saturday night was the most common night for these injuries". Alcohol was involved in 51\% of nighttime crashes, and in $31 \%$ of injuries in men and $17 \%$ of injuries in women. The injury severity score was significantly higher in those with maxillofacial injuries and when alcohol was involved $(p<0.001)$. There was a trend towards a decreased rate of maxillofacial injury in those wearing a helmet; however, it did not reach statistical significance $(p=0.35)$.

Holmes et al. documented 72 ATV-related collisions from the University of Alabama at Birmingham Trauma Registry [9]. They reported six (8.3\%) orbital floor fractures, and described five of them as "orbital floor blowout fractures". The authors found that the autumn and spring seasons had the highest frequency of ATV collisions, and that $67 \%$ of ATV collisions occurred on the weekends. When compared to patients involved in motorcycle crashes, ATV crashes were significantly more likely to result in maxillofacial fractures. The authors also found that those patients with maxillofacial injuries had longer hospital stays, lower Glasgow Coma Scale scores, and higher Injury Severity Score.

Bhutta et al. described 141 children with ATV-related admissions to a tertiary pediatric hospital in Arkansas [18]. They reported 10 orbital fractures and three "eye injuries". Fifty-three sustained extremity injuries, 34 head trauma, and 31 torso injuries. There was a significant association between brain injuries $(19 \%)$ and death or long-term disability $(20 \%)(p<0.001)$.

Whatley et al. included 11 children with maxillofacial fractures from LeBonheur Children's Medical Center in Memphis, Tennessee [19]. Three (27\%) sustained orbital fractures due to ATV-related injury, with two requiring craniotomies. 
Table 2. ATV-related orbital fractures. Drug use and use of ocular protection was not recorded for any study. ATV: all-terrain vehicle. RR: retrospective review. NI: no information. CSF: cerebrospinal fluid. CNS, central nervous system.

\begin{tabular}{|c|c|c|c|c|c|c|c|}
\hline Article & Study Type & Ocular Injuries & $\begin{array}{l}\text { Total ATV-Related } \\
\text { Injuries } \\
\end{array}$ & $\begin{array}{l}\begin{array}{l}\text { Mean Age } \\
(\% \text { Male })\end{array} \\
\end{array}$ & $\begin{array}{l}\text { \% Alcohol Use; } \\
\text { \% Helmet Use }\end{array}$ & Concomitant Injuries & Mechanism of Injury \\
\hline 1992 Demas [17] & $\begin{array}{l}\text { RR in a pediatric } \\
\text { hospital trauma center } \\
\text { in Pennsylvania from } \\
\text { 1988-1991 }\end{array}$ & $\begin{array}{l}2 \text { isolated orbital-zygomatic } \\
\text { fractures, } 2 \text { more had } \\
\text { "multiple midfacial" } \\
\text { fractures }\end{array}$ & $\begin{array}{l}35 \text { pediatric } \\
\text { ATV-related injuries }\end{array}$ & $\begin{array}{l}63 \% \text { were } \\
11-18 \text { years, } 34 \% \\
\text { were } 2-10 \text { years, } 1 \\
\text { was }<2 \text { years }(80 \%)\end{array}$ & $\begin{array}{l}0 \% ; 34 \% \text { wore } \\
\text { helmets, and } 31 \% \\
\text { had NI }\end{array}$ & $\begin{array}{l}63 \% \text { CNS, } 46 \% \text { extremity, } 29 \% \text { head, } \\
14 \% \text { cervical spine, } 6 \% \text { chest, } 14 \% \\
\text { abdominal }\end{array}$ & $\begin{array}{l}63 \% \text { roll/flip over, } \\
20 \% \text { stuck object, } \\
6 \% \text { cliff/embankment, } \\
11 \% \text { other, } 57 \% \text { driver, } \\
45 \% \text { passenger }\end{array}$ \\
\hline 1999 Marciani [7] & $\begin{array}{l}\text { RR in Kentucky from } \\
1995-1996\end{array}$ & $\begin{array}{l}7 \text { orbital floor fractures, } \\
2 \text { enucleations }\end{array}$ & $\begin{array}{l}72 \text { ATV-related } \\
\text { injuries }\end{array}$ & 28.1 years $(82 \%)$ & $\mathrm{NI} ; \mathrm{NI}$ & $\begin{array}{l}25(35 \%) \text { sustained maxillofacial } \\
\text { injuries, } 12 \text { had multiple facial } \\
\text { fractures, } 3 \text { deaths }\end{array}$ & $\begin{array}{l}40 \% \text { rollover, } 28 \% \text { collisions } \\
\text { with vehicles or stationary } \\
\text { objects, } 18 \% \text { fell/thrown, } \\
14 \% \text { unknown }\end{array}$ \\
\hline 1999 Touma [8] & $\begin{array}{l}\text { RR in West Virginia } \\
\text { from 1990-1996 }\end{array}$ & $\begin{array}{l}12 \text { orbital floor } \\
\text { fractures, } 1 \text { orbital rim } \\
\text { fracture, } 4 \text { suffered } \\
\text { "ophthalmic injuries" }\end{array}$ & $\begin{array}{l}153 \text { ATV-related } \\
\text { injuries }\end{array}$ & 26.4 years $(82 \%)$ & $22 \% ; 20 \%$ & $\begin{array}{l}\text { Of the } 33 \text { that sustained maxillofacial } \\
\text { injures, } 20 \text { had closed head injuries, } \\
9 \text { had orthopedic injuries, } 8 \text { had } \\
\text { temporal or basilar skull fractures, and } \\
6 \text { had skull fractures }\end{array}$ & $100 \%$ off-road \\
\hline 2004 Holmes [9] & $\begin{array}{l}\text { RR in Alabama from } \\
1998-2003\end{array}$ & 6 orbital floor fractures & 72 ATV collisions & 31 years $(82 \%)$ & $\mathrm{NI} ; \mathrm{NI}$ & $\begin{array}{l}\text { Concurrent with maxillofacial injuries: } \\
87 \% \text { neurologic, } 52 \% \text { skin, } \\
48 \% \text { orthopedic, } 1 \text { death }\end{array}$ & $\begin{array}{l}47 \% \text { ATV rollovers, } \\
23 \% \text { collision with } \\
\text { stationary object, } \\
30 \% \text { unknown }\end{array}$ \\
\hline 2004 Bhutta [18] & $\begin{array}{l}\text { RR from a pediatric } \\
\text { emergency department } \\
\text { in Arkansas from } \\
\text { 1998-2001 }\end{array}$ & $\begin{array}{l}10 \text { orbital fractures; } 3 \text { also } \\
\text { suffered "eye injuries" }\end{array}$ & $\begin{array}{l}141 \text { pediatric } \\
\text { ATV-related hospital } \\
\text { admissions }\end{array}$ & 11.6 years $(74 \%)$ & $\mathrm{NI} ; \mathrm{NI}$ & $\begin{array}{l}53 \text { extremity, } 31 \text { torso, } 27 \text { brain, } 4 \text { spinal } \\
\text { cord. } 23 \text { had long-term disability, } \\
22 \text { skull fractures, } 9 \text { epidural } \\
\text { hematomas, } 8 \text { subdural hematomas, } \\
8 \text { spinal fractures, } 5 \text { deaths }\end{array}$ & 105 drivers, 36 passengers \\
\hline 2005 Whatley [19] & $\begin{array}{l}\text { RR in Tennessee from } \\
1998-2003\end{array}$ & 3 orbital fractures & $\begin{array}{l}3 \text { ATV-related frontal } \\
\text { sinus fractures }\end{array}$ & 11 years $(100 \%)$ & $\mathrm{NI} ; \mathrm{NI}$ & $\begin{array}{l}2 \text { intraparenchymal hemorrhages, } \\
2 \text { CSF leaks, } 1 \text { pneumocephalus }\end{array}$ & \\
\hline 2006 Prigozen [11] & $\begin{array}{l}\text { RR from level I trauma } \\
\text { center in South Carolina } \\
\text { from 2001-2004 }\end{array}$ & $\begin{array}{l}14 \text { naso/orbital fractures. } \\
1 \text { patient suffered "visual } \\
\text { loss" secondary to optic } \\
\text { nerve compression from } \\
\text { subdural hematoma }\end{array}$ & $\begin{array}{l}26 \text { children with } \\
\text { ATV-related } \\
\text { craniofacial injuries }\end{array}$ & 13.1 years $(65 \%)$ & $\begin{array}{l}\text { Adults: } 46 \% ; 4 \% \\
\text { Children: NI; } 7.7 \%\end{array}$ & $\begin{array}{l}77 \% \text { of children had fractures of } \\
\text { facial/skull bones, } 1(3.8 \%) \text { death }\end{array}$ & $\begin{array}{l}\text { Adults/children: } \\
33.3 \% / 53.9 \% \text { loss of } \\
\text { control/roll-over } \\
45.2 \% / 26.9 \% \text { fall from } \\
\text { vehicle/ ejection } \\
19.1 \% / 19.2 \% \text { collision } \\
\text { with stationary object (tree, } \\
\text { fence, rock, parked car) } \\
2.4 \% / 0 \% \text { unknown } \\
76 \% / 65 \% \text { driver; } \\
24 \% / 35 \% \text { passenger } \\
\end{array}$ \\
\hline 2015 Rivera-Barrios [20] & $\begin{array}{l}\text { RR of } 2 \text { trauma centers } \\
\text { in South Carolina and } \\
\text { California from } \\
\text { 2001-2013 }\end{array}$ & 98 naso-orbital fractures & $\begin{array}{l}156 \text { ATV-related } \\
\text { craniofacial fractures }\end{array}$ & 28.4 years $(85.3 \%)$ & $\mathrm{NI} ; 36.5 \%$ & $\begin{array}{l}39.1 \% \text { frontal } / \text { skull base fractures, } \\
39.7 \% \text { maxillary /zygoma fractures, } \\
22.4 \% \text { mandibular fractures }\end{array}$ & \\
\hline
\end{tabular}


Prigozen et al. documented 26 children with ATV-related craniofacial injuries from Charleston Area Medical Center, a level I trauma center [11]. Fourteen (53.8\%) sustained nasal/orbital fractures. One $(3.8 \%)$ child suffered "visual loss" secondary to optic nerve compression from a subdural hematoma that was not responsive to evacuation and medical management. Most injuries occurred on weekends (31\% on Saturday, $23 \%$ on Sunday), and $46 \%$ occurred in the summer months (June-August). In addition, they found increased frequency of injuries in October and on Thursdays, which the authors believed coincided with various hunting seasons. The children presented with facial bone and skull fractures $(77 \%)$, contusions / lacerations/abrasions (62\%-69\%), as well as closed head injuries (35\%) that were significantly associated with mandibular fractures $(p=0.03)$. Seventy-two percent required operative intervention, $36 \%$ spent a mean of 5.1 days in the ICU, and $24 \%$ needed ventilator support. One $(3.8 \%)$ child died after severe head injury. Notably, the authors also briefly describe 84 adults with ATV-related craniofacial injuries.

Rivera-Barrios et al. described 156 ATV-related craniofacial fractures from two trauma centers: the Medical University of South Carolina and the University of California-San Diego [20]. Ninety-eight $(62.8 \%)$ sustained naso-orbital fractures. In this cohort, $29.7 \%$ were admitted to the ICU, and $21.8 \%$ of patients were intubated prior to arrival at the trauma center. The authors found a close relationship between those not wearing helmets $(63.5 \%)$ and the patients suffering traumatic brain injuries $(61.5 \%)$.

\subsection{Articles that Describe Pediatric ATV-Related Injuries and Mention Ocular Involvement}

Murphy et al. described 92 pediatric ATV-related injuries from a tertiary pediatric trauma center in Canada [21]. Three (3\%) had "eye" injuries that were otherwise not elaborated upon. Five (5\%) cases involved alcohol and drugs: three from teenage drivers, one impaired adult driver with an injured pediatric passenger, and one impaired motor vehicle driver that collided with a child ATV driver. Seventy-two percent of injuries occurred in the summer and fall. The authors found that helmet use was significantly associated with a reduced risk of head and facial injury (odds ratio, $0.02 ; 95 \%$ confidence interval, 0.001-0.101).

Mangano et al. described 185 pediatric ATV-related hospital admissions to the St. Louis Children's Hospital in Missouri [22]. Three (1.6\%) had "eye" injuries (additional details were not provided). Thirty-four percent of patients sustained neurologic injuries. Of this population, $42 \%$ of the injuries occurred in the summer, $58 \%$ were drivers, and included five driver/passenger pairs.

Wang et al. described 34 pediatric ATV-related injuries from the Memorial Hermann Children's Hospital, a level I pediatric trauma center [23]. Two $(6 \%)$ patients sustained TON requiring orbitotomy and optic nerve decompression. Five (15\%) patients sustained orbital fractures that did not require operative repair. Notably, ATV impact into barbed wire was the mechanism of injury for three $(9 \%)$ of the patients. 
Table 3. Pediatric ATV-related injuries with brief mention of ocular involvement. Use of ocular protection was not recorded for any study. ATV: all-terrain vehicle. RR: retrospective review. NI: no information.

\begin{tabular}{|c|c|c|c|c|c|c|c|}
\hline Article & Study Type & Ocular Injuries & $\begin{array}{l}\text { Total ATV-Related } \\
\text { Injuries }\end{array}$ & $\begin{array}{l}\text { Mean Age } \\
\text { (\% Male) }\end{array}$ & $\begin{array}{l}\text { \% Alcohol or Drug } \\
\text { Use; \% Helmet Use }\end{array}$ & Concomitant Injuries & Mechanism of Injury \\
\hline 2004 Murphy [21] & $\begin{array}{l}\text { RR in tertiary } \\
\text { pediatric trauma } \\
\text { center in Canada } \\
\text { from 1990-2002 }\end{array}$ & 3 "eye" injuries & 92 pediatric & 12.1 years $(73 \%)$ & $5 \% ; 69 \%$ & $\begin{array}{l}22 \text { head/facial, } 2 \text { neck, } \\
12 \text { trunk, } 66 \text { orthopedic, } \\
27 \text { external, } 2 \text { deaths } \\
(2.2 \% \text {, both secondary to } \\
\text { massive head injuries } \\
\text { with no helmet use) }\end{array}$ & $\begin{array}{l}28 \text { collision } \\
29 \text { roll/flip } \\
25 \text { fall/thrown } \\
9 \text { other } \\
51 \text { drivers } \\
29 \text { passengers }\end{array}$ \\
\hline 2006 Mangano [22] & $\begin{array}{l}\text { RR in pediatric } \\
\text { hospital in } \\
\text { Missouri from } \\
\text { 1993-2003 }\end{array}$ & 3 "eye" injuries & $\begin{array}{l}185 \text { pediatric ATV } \\
\text { admissions }\end{array}$ & 12.3 years $(70.3 \%)$ & $\mathrm{NI} ; 32 \%$ & $\begin{array}{l}33.5 \% \text { sustained } \\
\text { neurologic injuries, } \\
31 \% \text { sustained facial } \\
\text { or skull fractures, } \\
1.1 \%(\mathrm{n}=2) \text { died }\end{array}$ & $28 \%$ passengers \\
\hline 2007 Wang [23] & $\begin{array}{l}\text { RR in a level I } \\
\text { pediatric trauma } \\
\text { center in Texas } \\
\text { from 2002-2005 }\end{array}$ & $\begin{array}{l}2 \text { sustained traumatic } \\
\text { optic neuropathy, } \\
5 \text { sustained orbital } \\
\text { fractures }\end{array}$ & $\begin{array}{l}34 \text { ATV head /neck } \\
\text { injuries, all } \leq 16 \text { years }\end{array}$ & 12 years $(74 \%)$ & $\mathrm{NI} ; 25 \%$ & $\begin{array}{l}45 \% \text { CNS, } 28 \% \text { soft } \\
\text { tissue, } 15 \% \text { maxillofacial } \\
\text { fractures, } 8 \% \text { cervical } \\
\text { spine, } 8.8 \% \text { died }\end{array}$ & $\begin{array}{l}74 \% \text { drivers } \\
17 \% \text { passengers } \\
9 \% \text { unknown }\end{array}$ \\
\hline
\end{tabular}




\section{Discussion}

\subsection{Ocular Injuries}

Our literature review found that ocular injuries in ATV-related crashes are not uncommon. In the Mayercik et al. study, ocular or orbital injury occurred in $16.1 \%$ of ATV-related hospital admissions [6]. The most common ocular injury in the reviewed studies was orbital fracture. Eyelid lacerations, globe injury, optic nerve injury, diplopia, corneal abrasions, enophthalmos, restrictive strabismus, and traumatic cataract were also reported (Table 1). The co-incidence of non-ocular trauma was high among those with ocular ATV-related injuries, frequently including facial fractures and loss of consciousness (Table 1).

\subsection{Mechanism of Injury}

We found no major differences in the mechanisms of injury in studies reporting only ocular ATV-related injuries and in studies reporting non-ocular ATV-related injuries. Most of the injured were drivers rather than passengers, and ATV rollover was consistently the most common mechanism of injury. Interestingly, many papers report that summer months had the highest incidence of injury, and two $[8,11]$ reported that Saturday was the most common day of the week for ATV injuries.

\subsection{Drug and Alcohol Use}

Alcohol and recreational drug use are both risk factors for ATV crash and subsequent injury. Regarding ocular ATV-related injuries, Mayercik et al. reported a 20\% and 1\% incidence of alcohol and drug use, respectively [6]. In articles that also described non-ocular ATV-related injury, alcohol use varied from $0 \%-46 \%$, and drug use was generally not reported (Tables 2 and 3). Alcohol use was found to occur in both pediatric and adult injuries, and Murphy et al. reported one case [21] of an injured child passenger of an impaired adult ATV-driver.

\subsection{Helmet and Eye Protection Use}

In those sustaining ocular ATV-related injuries, helmet use varied from $0 \%-24 \%$ (Table 1). In articles that also described non-ocular ATV-related injury, helmet use varied from $4 \%-69 \%$. Pelletier et al. evaluated 435 patients with ATV-related injuries, and found that after controlling for age, sex, and blood alcohol content, helmet users were 2.3 times $(p=0.041)$ and 6.6 times $(p=0.016)$ less likely to sustain major head injury and die, respectively [24].

We found two economic cost analyses regarding helmet use on ATVs that support the use of head protection. Meyers et al. found that 238 head injuries and two fatalities per 100,000 ATV drivers could be averted by universal helmet use while riding on ATVs, saving US\$364,306 per injury [25]. Rodgers found significantly increased risk of death with no helmet use, male gender, larger engine sizes, and alcohol and drug use; he also found that helmeted drivers had a $42 \%$ lower fatality risk and a $64 \%$ lower risk of non-fatal head injury [26]. Rodgers calculated that helmet use (in 1990) could save $\$ 49.50$ annually per ATV driver (or about $\$ 25$, given the cost of helmets). Helmkamp found that states without ATV safety legislation had twice the ATV-related death rate of states with safety or helmet regulation [27].

The papers by Edmonson and Mayercik were the only ones to report the use of eye protection at the time of ATV-related injury, with both reporting that none of the patients wore eye protection at the time of injury. Mayercik et al. concluded that some of the ocular ATV-related injuries "could easily have been prevented by protective eyewear, whilst other may or may not have been preventable" [6]. They illustrated this with a case of a helmeted, intoxicated ATV driver struck in his eye by a rock, where eye protection could have shielded him.

It is worth noting that in the related field of motorcycle injury prevention, helmet laws have been shown to reduce the incidence and severity of facial injuries. In a study on the California Motorcycle Helmet Use Law, Kraus et al. found 27 facial injuries in the year prior to the law, and only 18 in the year after the law was enacted [28]. 
For motorcycles and ATVs, helmets have been shown to reduce both fatal and nonfatal head injuries. Since many of the ocular injuries in our literature review were co-incident with facial injuries, it is likely that similar helmet use laws could reduce ocular injuries associated with ATVs.

\subsection{Limitations}

A number of important limitations affect the generalizability of this literature review. Most of the reviewed articles report ATV-related injuries that presented to an emergency department or were admitted to a tertiary care hospital. This necessarily excludes many cases of milder injuries, including those presenting to community hospitals and ambulatory care centers, and those that did not require medical treatment at all. These bias our review towards more severe injuries, indicating that many more ATV-related ocular injuries may be milder than those reported here. We were also only able to find three articles that focused on ocular ATV-related injuries, and one was a case report.

\section{Conclusions and Recommendations}

Ocular and orbital trauma can be found in many cases of ATV-related injury. While injuries most commonly include orbital fractures and lid laceration, more severe manifestations such as TON, optic nerve laceration, retinal detachment, vitreous hemorrhage, and ruptured globe have been reported. These ocular and orbital sequelae frequently require costly surgical interventions, and may result in long-term disability as well as legal and permanent blindness [29]. Severe head injury and neurological impairment are also common in ATV crashes. Careful ophthalmologic examination is essential in patients with head injury, as pupillary involvement, optic nerve injury, and ocular motor paresis have been shown to be associated with more severe head injury.

Many authors have suggested that it may be possible to prevent or ameliorate the vast majority of the above-mentioned ophthalmologic and neurologic injuries. Many authors have suggested methods to help prevent ATV-related crashes and decrease the morbidity and mortality from them when they do occur, including: (1) minimum age of 16 years for independent operation or mandatory parental supervision for those $<16$ years of age; (2) automobile driver's license or permit or educational classes with "hands-on" training; (3) head and eye protection during ATV operation; (4) abstention from alcohol and illicit drugs; (5) single operator only (i.e., no passengers); and (6) avoidance of public roadways $[5,6,8,11-13,30,31]$. Similar efforts have been shown to reduce injury severity from motorcycles [32]. Avoidance of public roadways is particularly important, as ATVs are designed for off-road surfaces. Over half of all U.S. deaths related to ATVs occur on public roadways, and the majority of these do not involve a collision with a motor vehicle [13].

We believe that these methods to reduce ATV morbidity would also reduce ATV-related ocular injuries. The recommendation to wear helmets with eye protection, in particular, has been shown to reduce facial injuries associated with motorcycle use, and would almost certainly decrease facial and ocular injuries associated with ATV use as well.

Acknowledgments: This study is supported by National Institutes of Health CORE Grant P30 EY008098, Eye and Ear Foundation of Pittsburgh, PA, Unrestricted Grant from Research to Prevent Blindness, New York, NY.

Author Contributions: The literature review was conducted by Elliot S. Crane and Anton M. Kolomeyer. The manuscript was written, reviewed, and approved for submission by Elliot S. Crane, Anton M. Kolomeyer and Andrew W. Eller.

Conflicts of Interest: The authors declare no conflict of interest. 


\section{Appendix A}

Medline Search

\begin{tabular}{lll}
\hline 1 & Off-Road Motor Vehicles/ or atv.mp & 1141 \\
2 & all terrain vehicle.mp & 245 \\
3 & 1 or 2 & 1195 \\
4 & orbital.mp or Orbital Fractures/ & 40442 \\
5 & (ocular or ophthalmic or eye).mp & 390383 \\
6 & Maxillofacial Injuries/ & 3630 \\
7 & Craniocerebral Trauma/ & 20460 \\
8 & 4 or 5 or 6 or 7 & 441771 \\
9 & 3 and 8 & 61 \\
\hline
\end{tabular}

Sixty-one titles and abstracts were reviewed for relevance.

\section{References}

1. Topping, J. 2014 Annual Report of ATV-Related Deaths and Injuries; CPSC: Bethesda, MD, USA, 2015. Available online: http:/ /www.cpsc.gov/Global/Research-and-Statistics/Injury-Statistics/Sports-and-Recreation/ ATVs/2014atvannualreport.pdf (accessed on 3 June 2016).

2. United States v. American Honda Motor Co., et. al., Civ. No. 87-3525 (D.D.C. 352528 April 1988, The United States District Court for the District of Columbia 1988), 28 April 1988.

3. Kosh, M.A. Standards for All Terrain Vehicles and Ban of Three-Wheeled All Terrain Vehicles; Notice of Proposed Rulemaking; CPSC: Bethesda, MD, USA, 2006. Available online: http://www.cpsc.gov/pagefiles/84803/ atv2006_3.pdf (accessed on 3 November 2015).

4. e-CFR § 1420; CPSC: Bethesda, MD, USA, 2012. Available online: http://www.ecfr.gov/cgi-bin/ text-idx?SID=b8d11519e9ffe3559ce05d92d00ca2ef\&mc=true\&node=pt16.2.1420\&rgn=div5 (accessed on 16 August 2016).

5. Edmonson, B.C.; Wilson, M.W.; Fleming, J.C.; Haik, B.G. Ophthalmic injuries in children involved in all-terrain vehicle crashes. Ophthalmic Plast. Reconstr. Surg. 2004, 20, 99-102. [CrossRef]

6. Mayercik, V.A.; Eller, A.W.; Stefko, S.T. Ocular injuries in all-terrain-vehicle accidents. Injury 2012, 43, 1462-1465. [CrossRef] [PubMed]

7. Marciani, R.D.; Caldwell, G.T.; Levine, H.J. Maxillofacial injuries associated with all-terrain vehicles. J. Oral Maxillofac. Surg. 1999, 57, 119-123. [CrossRef]

8. Touma, B.J.; Ramadan, H.H.; Bringman, J.J.; Rodman, S. Maxillofacial injuries caused by all-terrain vehicle accidents. Otolaryngol Head Neck Surg. 1999, 121, 736-739. [CrossRef] [PubMed]

9. Holmes, P.J.; Koehler, J.; McGwin, G., Jr.; Rue, L.W., III. Frequency of maxillofacial injuries in all-terrain vehicle collisions. J. Oral Maxillofac. Surg. 2004, 62, 697-701. [CrossRef] [PubMed]

10. Ashar, A.; Kovacs, A.; Khan, S.; Hakim, J. Blindness associated with midfacial fractures. J. Oral Maxillofac. Surg. 1998, 56, 1146-1150. [CrossRef]

11. Prigozen, J.M.; Horswell, B.B.; Flaherty, S.K.; Henderson, J.M.; Graham, D.A.; Armistead, L.M.; Habib, J.H.; Lukowski, D.E. All-terrain vehicle-related maxillofacial trauma in the pediatric population. J. Oral Maxillofac. Surg. 2006, 64, 1333-1337. [CrossRef] [PubMed]

12. Jennissen, C.A.; Harland, K.K.; Wetjen, K.M.; Denning, G.M. The Effect of Passengers on All-Terrain Vehicle Crash Mechanisms and Injuries. Safety 2016, 2, 1. [CrossRef]

13. Denning, G.M.; Jennissen, C.A. All-terrain vehicle fatalities on paved roads, unpaved roads, and off-road: Evidence for informed roadway safety warnings and legislation. Traffic Inj. Prev. 2016, 17, 406-412. [CrossRef] [PubMed]

14. Committee on Injury and Poison Prevention. All-Terrain Vehicle Injury Prevention: Two-, Three-, and Four-Wheeled Unlicensed Motor Vehicles. Pediatrics 2000, 105, 1352-1354.

15. Cvijanovich, N.Z.; Cook, L.J; Mann, C.; Dean, M.J. A Population-Based Assessment of Pediatric All-Terrain Vehicle Injuries. Pediatrics 2001, 108, 631-635. [CrossRef] [PubMed] 
16. Close, J.K.; Shiels, W.E., II; Foster, J.A.; Powell, D.A. Percutaneous Ultrasound-Guided Intraorbital Foreign Body Removal. Ophthalmic Plast. Reconstr. Surg. 2009, 25, 335-337. [CrossRef] [PubMed]

17. Demas, P.N.; Braun, T.W. Pediatric Facial Injuries Associated with All-Terrain Vehicles. J. Oral Maxillofac. Surg. 1992, 50, 1280-1283. [CrossRef]

18. Bhutta, S.T.; Greenberg, S.B.; Fitch, S.J.; Parnell, D. All-Terrain Vehicle Injuries in Children: Injury Patterns and Prognostic Implications. Pediatr. Radiol. 2004, 34, 130-133. [CrossRef] [PubMed]

19. Whatley, W.S.; Allison, D.W.; Chandra, R.K.; Thompson, J.W.; Boop, F.A. Frontal Sinus Fractures in Children. Laryngoscope 2005, 115, 1741-1745. [CrossRef] [PubMed]

20. Rivera-Barrios, A.E.; Brown, S.; Reid, C.M.; Hassanein, A.H.; Coimbra, R.; Dobke, M.; Herrera, F.A., Jr. Craniofacial Fracture Patterns in All Terrain Vehicle Injuries. Ann. Plast. Surg. 2015, 74, S229-S230. [CrossRef] [PubMed]

21. Murphy, N.; Yanchar, N.L. Yet More Pediatric Injuries Associated with All-Terrain Vehicles: Should Kids Be Using Them? J. Trauma 2004, 56, 1185-1190. [CrossRef] [PubMed]

22. Mangano, F.T.; Menendez, J.A.; Smyth, M.D.; Leonard, J.R.; Narayan, P.; Park, T.S. Pediatric neurosurgical injuries associated with all-terrain vehicle accidents: A 10-year experience at St. Louis Children's Hospital. J. Neurosurg. 2006, 105 (Suppl. S1), 2-5. [CrossRef] [PubMed]

23. Wang, B.S.; Smith, S.L.; Pereira, K.D. Pediatric Head and Neck Trauma from All-Terrain Vehicle Accidents. Otolaryngol. Head Neck Surg. 2007, 137, 201-205. [CrossRef] [PubMed]

24. Pelletier, J.-S.; McKee, J.; Ozegovic, D.; Widder, S. Retrospective review of all-terrain vehicle accidents in Alberta. Can. J. Surg. 2012, 55, 249-253. [CrossRef] [PubMed]

25. Myers, M.L. Cost Effectiveness of Wearing Head Protection on All-Terrain Vehicles. J. Agromed. 2009, 14, 312-323. [CrossRef] [PubMed]

26. Rodgers, G.B. The Effectiveness of Helmets in Reducing All-Terrain Vehicle Injuries and Deaths. Accid. Anal. Prev. 1990, 22, 47-58. [CrossRef]

27. Helmkamp, J.C. A Comparison of State-Specific All-Terrain Vehicle-Related Death Rates, 1990-1999. Am. J. Public Health 2001, 91, 1792-1795. [CrossRef] [PubMed]

28. Peek-Asa, C.; Kraus, J.F. Estimates of injury impairment after acute traumatic injury in motorcycle crashes before and after passage of a mandatory helmet use law. Ann. Emerg. Med. 1997, 29, 630-636. [CrossRef]

29. Kulkarni, A.R.; Aggarwal, S.P.; Kulkarni, R.R.; Deshpande, M.D.; Walimbe, P.B.; Labhsetwar, A.S. Ocular manifestations of head injury: A clinical study. Eye 2005, 19, 1257-1263. [CrossRef] [PubMed]

30. Helmkamp, J.C. Family fun-Family tragedy: ATV-related deaths involving family members. Inj. Prev. 2007, 13, 426-428. [CrossRef] [PubMed]

31. Aitken, M.E.; Graham, C.J.; Killingsworth, J.B.; Mullins, S.H.; Parnell, D.N.; Dick, R.M. All-terrain vehicle injury in children: Strategies for prevention. Inj. Prev. 2004, 10, 303-307. [CrossRef] [PubMed]

32. Mock, C.N.; Maier, R.V.; Boyle, E.; Pilcher, S.; Rivara, F.P. Injury prevention strategies to promote helmet use decrease severe head injuries at a level I trauma center. J. Trauma 1995, 39, 29-33. [CrossRef] [PubMed]

(C) 2016 by the authors; licensee MDPI, Basel, Switzerland. This article is an open access article distributed under the terms and conditions of the Creative Commons Attribution (CC-BY) license (http://creativecommons.org/licenses/by/4.0/). 